\title{
Evaluation of local hemostatic effect of microporous polysaccharide hemospheres products in thyroid surgery: a prospective randomized controlled study
}

\author{
Enver Kunduz ${ }^{1}$, Erhan Aysan ${ }^{1}$, Ufuk Oğuz İdiz ${ }^{2}$, Yeliz Emine Ersoy ${ }^{1}$, Hüseyin Kazım Bektaşoğlu ${ }^{1}$, Samet Yığman ${ }^{1}$, Hacer Kundakcıoğlu ${ }^{1}$ \\ ${ }^{1}$ Department of General Surgery, Bezmialem Vakif University School of Medicine, Istanbul, Turkey \\ ${ }^{2}$ Clinic of General Surgery, Istanbul Training and Research Hospital, Istanbul, Turkey
}

\begin{abstract}
Objective: Bleeding is a rare and dangerous complication of thyroid surgery. One of the hemostatic agents used during surgery are microporous polysaccharide hemospheres (MPH) which are local hemostatic agents acquired from purified potato starch. The aim of this study was to evaluate the efficiency of two MPH, produced with different biotechniques, in decreasing hemorrhages and drainage following thyroidectomy.

Material and Methods: A statistical power analysis predicted that totally 20 patients per each group was needed within $95 \%$ confidential interval. Patients were randomized into 3 groups as control, Haemocer TM and Arista TM to be 20 patients in each group. Following bilateral total thyroidectomy, no additional procedures were performed in the first group, $5 \mathrm{~g}$ Haemocer was administered to the second group, $5 \mathrm{~g}$ Arista was administered to the third group into the operational field, and the operation was ended by placing a double-sided hemovac drain. At post-operative day one, drainage amount, calcium (Ca), phosphate (P) and parathyroid hormone (PTH) levels were noted.

Results: No significant difference was noted between the groups for age, gender, removed tissue weight and malignant pathology rates. Also, no significant difference was noted between post-operative drainages and Ca, P, PTH levels of groups either. Hoarseness or hematoma were not observed in any patient.
\end{abstract}

Conclusion: MPHs are not proven in effectiveness in decreasing post-operative hemorrhages, which might be a key to avoiding unnecessary expenses. Keywords: Microporous, polysaccharide, hemospheres, thyroid, hemostasis

Cite this article as: Kunduz E, Aysan E, Idiz UO, Ersoy YE, Bektaşoğlu HK, Yığman S, et al. Evaluation of local hemostatic effect of microporous polysaccharide hemospheres products in thyroid surgery: a prospective randomized controlled study. Turk J Surg 2019; 35 (1): 49-53

Corresponding Author

Enver Kunduz

E-mail: drkunduz@yahoo.com

Received: 22.03.2018

Accepted: 18.07.2018

Available Online Date: 01.03 .2019

o Copyright 2019 by Turkish Surgical Society Available online at www.turkjsurg.com

DOI: $10.5578 /$ turkjsurg.4162

\section{INTRODUCTION}

Thyroidectomy operation is one of the most common endocrine surgical procedures worldwide (1). Thyroidectomy is frequently performed for nodular goiter and thyroid cancer. Major complications include laryngeal nerve injury, hypoparathyroidism and wound complications (hematoma, seroma, infection etc.) (2-5).

Hemostasis is critical during surgery. Inadequate hemostasis can cause postoperative hematoma, wound dehiscence, infection and prolonged hospital stay (6). Most of the time, adequate hemostasis is ensured with proper surgical method, electrocauterization, suturation and bipolar sealing devices $(5,7,8)$. Additionally, adrenaline packs and local hemostatic agents can be used for oozing hemorrhages ( 9 ).

Bleeding is a rare complication of thyroid surgery. However, when it occurs, it carries severe morbidity and mortality risks (10-12). Even a hemorrhage of 20-30 $\mathrm{ml}$ may result in death by causing tracheal compression and airway obstruction (13). To prevent this complication, generally drainage tubes are placed during the surgical procedure.

One of the hemostatic agents used during surgery is microporous polysaccharide hemospheres (MPH) which are local hemostatic agents derived as a product of advanced BioEngineering from purified potato starch. MPH incorporate 
a sophisticated, plant-based polymer crosslinking that creates ultra-hydrophilic, biocompatible particles. They facilitate the coagulation cascade by absorbing the liquid portion of the blood and increasing the concentration of the platelets and coagulation factors (14-16). Clotting process begins on contact, regardless of patient's coagulation status. MPH provides broad area coverage on rough surfaces and in hard-to-reach areas. MPH are indicated in surgical procedures except neurologic and ophthalmic as an adjunctive hemostatic device to assist when control of capillary, venous, and arteriolar bleeding by pressure, ligature, and other conventional procedures are ineffective or impractical.

This study aimed to evaluate the efficiency of two MPH, produced with different biotechniques including Haemocer TM and Arista TM, in decreasing hemorrhages and drainage following thyroidectomy. Thereby, an effective hemostatic agent would ensure better cosmetic results and extinguish drainage replacement.

\section{MATERIAL and METHODS}

Totally, 60 patients (20 patients per each group) were predicted in statistical power analysis within 95\% confidence interval. Subsequent to local human ethics committee approval, a group of 60 patients ( 12 males, 48 females, average age: 45 , age range: $12-67$ years) were enrolled prospectively. Study group consisted of euthyroid patients admitted to the Endocrine surgery outpatient clinic between January and December 2013, and scheduled to undergo total thyroidectomy. Thyroidectomy indications were malignancy, suspicious malignancy, nodules larger than $4 \mathrm{~cm}$, Basedow-Graves disease and symptomatic multi-nodular goitre like dyspnea and etc. Informed consent was obtained from all participants for both the operation they would undergo and the study they would be enrolled in. Exclusion criteria were administration of anticoagulant agents, central or/and lateral lymph node dissection for malignancy or for any reason, and patient refusal of operation or study participation. Patients were divided into three groups; first being the control group, second being Haemocer ${ }^{\mathrm{TM}}$ (Bio Cer Entwicklungs-GmbH, Bayreuth, Germany) group and third being Arista $^{\text {TM }}$ (Bard Davol Inc., Werwick, United Kingdom) group respectively. The three treatments are randomized on
Microsoft Excel $2016^{\circledR}$ program for 20 patients in each group. The researcher informed the surgeon in the operation room for each patient. First operation belonging to the control group, all 60 patients underwent the procedure consequently. The same surgeon performed bilateral total thyroidectomy on all patients. Following bilateral total thyroidectomy, no additional procedures were performed in the first group, $5 \mathrm{~g}$ Haemocer TM was administered to the second group, $5 \mathrm{~g}$ Arista TM was administered to the third group into the operational field. And the operation was ended by placing a double-sided hemovac drain. The thyroidectomy material was weighted perioperatively. Although there is not any effect for hypocalcemia of $\mathrm{MPH}$, they may cause hypoperfusion of the parathyroid glands while covering the surgical site for hemostasis. On post-operative day one, drainage amount, calcium (Ca), phosphate (P) and parathyroid hormone (PTH) levels were noted.

\section{Statistical Analysis}

Totally, 60 patients (20 patients per each group) were predicted in statistical power analysis within $95 \%$ confidence interval. The statistical analyses were performed using SPSS v20. KruskalWallis Chi-Square test was used for intergroup comparison. Data was evaluated within 95\% Confidence Interval and with $p<0.05$ significance level.

\section{RESULTS}

Information regarding age, gender, removed tissue weight and malignant pathology rates of the groups are shown on Table 1. No significant difference was noted between the groups for age, gender, removed tissue weight and malignant pathology rates.

No significant difference was noted between post-operative drainages and Ca, P, PTH levels of the groups, either. Hoarseness, surgical site infection or hematoma was not observed in any patient. Post-operative day one drainage amounts and $\mathrm{Ca}$, P, PTH levels are shown on Table 2.

On post-operative day one, asymptomatic hypocalcemia was noted for four patients in group one, two patients in group two and four patients in group three. Outpatient clinic controls revealed normal calcium levels for all patients on post-operative day 15 after conservative follow-up.

Table 1. Information regarding age, removed tissue weight averages, gender and malignant pathology of the groups

\begin{tabular}{|c|c|c|c|c|}
\hline & $\begin{array}{l}\text { Group } 1 \\
\text { (Control) }\end{array}$ & $\begin{array}{c}\text { Group } 2 \\
\text { (Haemocer }^{\mathrm{TM}} \text { ) }\end{array}$ & $\begin{array}{c}\text { Group } 3 \\
\text { (Arista }^{T M} \text { ) }\end{array}$ & $\mathrm{p}$ \\
\hline Age & $46.0 \pm 10.8$ & $44.8 \pm 13.1$ & $43.9 \pm 13.0$ & 0.946 \\
\hline Gender (female: male) & $17: 3$ & $15: 5$ & $16: 4$ & 0.743 \\
\hline Tissue weight (g) & 99.7 & 66.3 & 50.5 & 0.129 \\
\hline Malignant pathology & $7 / 20$ & $6 / 20$ & $9 / 20$ & 0.617 \\
\hline
\end{tabular}




\begin{tabular}{|l|c|c|c|c|}
\hline Table 2. Post-operative drainage; Ca, P, PTH level averages of the groups & $\begin{array}{c}\text { Group 2 } \\
\text { (Haemocer) }\end{array}$ & $\begin{array}{c}\text { Group 3 } \\
\text { (Arista) }\end{array}$ & p \\
\hline Drainage amount $(\mathrm{mL})$ & $53.53 \pm 22.41$ & $43.68 \pm 27.90$ & $51.94 \pm 38.70$ & 0.435 \\
\hline Serum $\mathrm{Ca}(\mathrm{mg} / \mathrm{dL})$ & $8.32 \pm 0.70$ & $8.27 \pm 0.81$ & $8.19 \pm 1.05$ & 0.517 \\
\hline Serum P $(\mathrm{mg} / \mathrm{dL})$ & $3.30 \pm 1.13$ & $3.42 \pm 0.77$ & $3.26 \pm 0.99$ & 0.741 \\
\hline PTH $(\mathrm{pg} / \mathrm{mL})$ & $32.30 \pm 27.10$ & $40.16 \pm 26.58$ & $23 \pm 31.37$ & 0.124 \\
\hline Ca: Calcium; P: Phosphate; PTH: Parathyroid hormone. & & & \\
\hline
\end{tabular}

\section{DISCUSSION}

Since the day it was identified, haemorrhage has been one of the most feared complications of thyroidectomy. Despite the advances in surgical method and instruments with its rare occurrence; post-operative hematoma remains to cause severe mortality and morbidity risks $(9,11)$.

Post-operative hematoma may cause airway obstruction due to larynx compression and impairment in venous and lymphatic drainage $(11,12)$.

Slipping of ligatures, re-opening of coagulated veins or leakage from remnant thyroid tissue have been suggested for the etiology of bleeding following thyroidectomy $(11,12)$. Hurtado et al. have stated that postoperative bleeding is present in patients with remnant thyroid tissue, especially the ones with hyperfunctioning thyroid diseases; yet they have failed to prove it statistically (17). Bergamashi et al. have not been able to show the association between the extension of thyroidectomy and post-operative hematoma either (18). However; in a large multicentered study, hematoma consisted $8 \%$ of all complications, and with a rate of $2 \%$, it has been found to be most frequent in patients with bilateral subtotal thyroidectomy operation (19). Primary efficiency of local hemostatic agents are seen in oozing hemorrhages (7).

$\mathrm{MPH}$ are relatively new additions to the hemostatic agents family. They are acquired from purified potato starch. Absorbing the liquid portion of the blood, they increase the concentration of platelets and coagulation factors and facilitate the coagulation cascade. By this way, a thick, viscose clot formation occurs and then fibrin coat takes place (14-16).

Local hemostatic agents are involved in different fields clinically. They are especially used in liver resections, spleen injuries, kidney operations and orthopedic surgery frequently $(14-16,20)$. For their experimental animal study, Humphrays et al. have evaluated the use of MPH in iatrogenic spleen injuries. Except for one case of splenic artery injury of 12 lesions, MPH have been proven effective in spleen parenchymal injuries (14).

Rajagopal and Hakim have assessed the hemostatic efficiency of MPH on 44 living nephrectomy donors and found hemostasis to be successful for all donors. Therefore, they have stated MPH are efficient and safe hemostatic agents that decrease post-operative complications (21).

There are various studies on local hemostatic agent use in thyroid surgery. Amit M et al., in their randomized prospective study conducted on 190 patients, have compared the efficiency of oxidized cellulose patch hemostatic agent Surgice ${ }^{\circledR}{ }^{(E t h i c o n}$ Johnson\&Johnson Corp., New Jersey, USA) in thyroid surgery. Group one $(n=92)$ has received conventional treatment while group two $(n=98)$ has had Surgicel ${ }^{\circledR}$ (Ethicon Johson\&Johnson Corp., New Jersey, USA) in addition to the conventional treatment. No statistically significant difference has been noted between the groups in terms of operation duration, drainage amount and post-operative complications. Duration of hospital stay and drain removal have been found to be significantly shorter for the conventional group ( $p<0.001)$. As a result, routine hemostatic agent use has not been suggested in thyroid surgery (22).

Testini et al. have compared the local hemostatic agent Flosea ${ }^{\circledR}$ (Baxter Healthcare Johnson\&Johnson Corp., Illinois,USA) with conventional surgical hemostasis techniques and oxidized regenerated cellulose patch (Tabotamp Fibrillar ${ }^{\circledR} 2.5 \times 5 \mathrm{~cm}$, Ethicon Johnson\&Johnson Corp., New Jersey, USA) in their study of 155 patients. Duration of operation (Floseal vs Surgery, 105 vs 133 min, $p=0.02$; Floseal vs. Tabotamp, 105 vs. $122 \mathrm{~min}, \mathrm{p}=0.0003$ ), drain removal (Floseal vs. Surgery $p=0.006$, Floseal vs. Tabotamp $p=0.008$ ) and hospital stay (Floseal vs. Surgery $p=0.02$, Floseal vs. Tabotamp $p=0.002$ ) have been determined significantly lower for Floseal (23). Also, Sielaff et al., in their multi-centre study, have assessed the efficiency of gelatine-based sponge as a local hemostatic agent in thyroid surgery. According to the results of 87 thyroidectomy cases, it has been found to be safe and efficient as a local hemostatic agent in thyroid surgery (24).

To the best of our knowledge, this is the first study to evaluate the efficiency of Haemocer ${ }^{\mathrm{TM}}$ and Arista $^{\mathrm{TM}}$ in thyroid surgery.

This study addressed the efficiency of MPH produced with two different biotechniques, Haemocer ${ }^{\mathrm{TM}}$ and Arista $^{\mathrm{TM}}$, in terms of post-operative haemorrhage and drainage amounts. Decrease in post-operative haemorrhage was observed for Haemocer ${ }^{\mathrm{TM}}$ and Arista $^{\mathrm{TM}}$; however, statistical significance could not have 
been achieved. Neither product has been found to be superior in terms of bleeding reducing activity. MPH administration had no effect on post-operative Ca, P and PTH levels. It did not affect the hoarseness and infection rates either.

\section{CONCLUSION}

$\mathrm{MPH}$ are relatively expensive products that got in use empirically in thyroid surgery. However, there is no scientific evidence regarding their role in thyroid surgery. Based on data from our study, MPH are yet to be proven effective in decreasing postoperative hemorrhages and this might be a key to avoiding unnecessary expenses.

Ethics Committee Approval: Ethics committee approval was received for this study from the Ethics Committee of Bezmialem Vakif University (2013/439).

Informed Consent: Written informed consent was obtained from patient who participated in this study.

Peer-review: Externally peer-reviewed.

Author Contributions: Consept - E.A., E.K.; Design - E.K., E.A.; Supervision - E.A., Y.E.E.; Resource - E.K., O.I.; Materials - O.I.; Data Collection and/or Processing - Y.E.E.; H.K.B.; Analysis and Interpretation - E.K., S.Y.; Literature Search - E.K., S.Y., H.K.; Writing Manuscript - E.K., O.l.; Critical Reviews - E.K, E.A.

Conflict of Interest: The authors have no conflicts of interest to declare.

Financial Disclosure: The authors declared that this study has received no financial support.

\section{REFERENCES}

1. Karamanakos SN, Markou KB, Panagopoulos K, Karavias D, Vagianos $C E$, Scopa CD, et al. Complications and risk factors related to the extent of surgery in thyroidectomy. Results from 2,043 procedures. Hormones (Athens). 2010; 9: 318-25. [CrossRef]

2. Ho TW, Shaheen AA, Dixon E, Harvey A. Utilization of thyroidectomy for benign disease in the United States: a 15-year population-based study. Am J Surg 2011; 201:570-4. [CrossRef]

3. Bergenfelz A, Jansson S, Kristoffersson A, Mårtensson H, Reihnér E, Wallin $G$, et al. Complications to thyroid surgery: results as reported in a database from a multicenter audit comprising 3,660 patients. Langenbecks Arch Surg 2008; 393: 667-73. [CrossRef]

4. Lang $B H, Y$, $P$ PC, LO CY. A review of risk factors and timing for postoperative hematoma after thyroidectomy: is outpatient thyroidectomy really safe? World J Surg 2012; 36: 2497-502. [CrossRef]

5. Ecker T, Carvalho AL, Choe JH, Walosek G, Preuss KJ. Hemostasis in thyroid surgery: harmonic scalpel versus other techniques--a metaanalysis. Otolaryngol Head Neck Surg 2010; 143: 17-25. [CrossRef]

6. Schreiber MA, Neveleff DJ. Achieving hemostasis with topical hemostats: making clinically and economically appropriate decisions in the surgical and trauma settings. AORN J 2011; 94: S1-20. [CrossRef]

7. Emilia M, Luca S, Francesca B, Luca B, Paolo S, Giuseppe F, et al. Topical hemostatic agents in surgical practice. Transfus Apher Sci 2011; 45: 305-11. [CrossRef]
8. Tokgöz H, Bektaş S, HancI V, Erol B, Akduman B, Karakaya K, et al. Postoperative adhesions after application of topical hemostatic agents: outcomes in a rat partial nephrectomy model. Urology 2011; 78: 970. e9-14. [CrossRef]

9. Ersoy YE, Aysan E, Meric A, Kadıoglu H, Cengiz MB, Bozkurt S, et al. Does adrenaline spraying over thyroidectomy area reduce bleeding? Int J Clin Exp Med 2014; 7: 274-9.

10. Guler M, Maralcan G, Kul S, Baskonus I, Yilmaz M. The efficacy of Ankaferd Blood Stopper for the management of bleeding following total thyroidectomy. J Invest Surg 2011; 24: 205-10. [CrossRef]

11. Harding J, Sebag F, Sierra M, Palazzo FF, Henry JF. Thyroid surgery: postoperative hematoma--prevention and treatment. Langenbecks Arch Surg 2006; 391: 169-73. [CrossRef]

12. Lee HS, Lee BJ, Kim SW, Cha YW, Choi YS, Park YH, et al. Patterns of postthyroidectomy hemorrhage. Clin Exp Otorhinolaryngol 2009; 2: 72-7. [CrossRef]

13. Dionigi G, Bacuzzi A, Bertocchi V, Carrafiello G, Boni L, Rovera F, et al. Safe incorporation of new technologies in thyroid surgery. Expert Rev Med Devices 2008; 5: 747-58. [CrossRef]

14. Humphreys MR, Castle EP, Andrews PE, Gettman MT, Ereth MH. Microporous polysaccharide hemospheres for management of laparoscopic trocar injury to the spleen. Am J Surg 2008; 195: 99-103. [CrossRef]

15. Seyednejad H, Imani M, Jamieson T, Seifalian AM. Topical haemostatic agents. Br J Surg 2008; 95: 1197-225. [CrossRef]

16. Ho J, Hruza G. Hydrophilic polymers with potassium salt and microporous polysaccharides for use as hemostatic agents. Dermatol Surg 2007; 33: 1430-3.[CrossRef]

17. Hurtado-López LM, Zaldivar-Ramirez FR, Basurto Kuba E, Pulido Cejudo A, Garza Flores JH, Muńoz Solis O, et al. Causes for early reintervention after thyroidectomy. Med Sci Monit 2002; 8: CR247-50.

18. Bergamaschi R, Becouarn G, Ronceray J, Arnaud JP. Morbidity of thyroid surgery. Am J Surg 1998; 176: 71-5. [CrossRef]

19. Rosato L, Avenia N, Bernante P, De Palma M, Gulino G, Nasi PG, et al. Complications of thyroid surgery: analysis of a multicentric study on 14,934 patients operated on in Italy over 5 years. World J Surg 2004 28:271-6. [CrossRef]

20. Humphreys MR, Lingeman JE, Terry C, Castle EP, Andrews PE, Gettman MT, et al. Renal injury and the application of polysaccharide hemospheres: a laparoscopic experimental model. J Endourol 2008; 22: 1375-81. [CrossRef]

21. Rajagopal P, Hakim N. The use of a powdered polysaccharide hemostat (HemoStase) in live donor nephrectomies controls bleeding and reduces postoperative complications. Transplant Proc 2011; 43: 424-6. [CrossRef]

22. AmIt MI, BInenbaum Y, Cohen JT, Gil Z. Effectiveness of an oxidized cellulose patch hemostatic agent in thyroid surgery: a prospective, randomized, controlled study. J Am Coll Surg 2013; 217:221-5. [CrossRef]

23. Testini M, Marzaioli R, Lissidini G, Lippolis A, Logoluso F, Gurrado A, et al. The effectiveness of FloSeal matrix hemostatic agent in thyroid surgery: a prospective, randomized, control study. Langenbecks Arch Surg 2009; 394: 837-42. [CrossRef]

24. Sielaff M, Hermanns M, Uhlig R, Abou-Ghazalé T, Steinmüller T. Early experience with a novel gelatine-based sponge for local haemostasis in thyroid surgery. In Vivo 2014; 28: 255-8. 


\title{
ORIJINAL ÇALIŞMA-ÖZET
}

Turk J Surg 2019; 35 (1): 49-53

\section{Mikro gözenekli polisakkarit hemosfer ürünlerinin tiroid cerrahisinde lokal hemostatik etkilerinin değerlendirilmesi: Prospektif randomize kontrollü çalışma}

\author{
Enver Kunduz ${ }^{1}$, Erhan Aysan ${ }^{1}$, Ufuk Oğuz İdiz ${ }^{2}$, Yeliz Emine Ersoy ${ }^{1}$, Hüseyin Kazım Bektaşoğlư ${ }^{1}$ Samet Yığman ${ }^{1}$, Hacer Kundakcıoğlu ${ }^{1}$ \\ ${ }^{1}$ Bezmialem Vakıf Üniversitesi Tıp Fakültesi, Genel Cerrahi Anabilim Dalı, İstanbul, Türkiye \\ ${ }^{2}$ Istanbul Eğitim ve Araştırma Hastanesi, Genel Cerrahi Kliniği, İstanbul, Türkiye
}

\section{ÖZET}

Giriş ve Amaç: Kanama tiroid cerrahisinin nadir ve tehlikeli bir komplikasyonudur. Ameliyat sırasında kullanılan hemostatik ajanlardan biri, saflaştırılmış patates nişastasından elde edilen lokal hemostatik ajanlar olan mikro gözenekli polisakkarit hemosferlerdir (MPH). Bu çalışmanın amacı, farkıı biyotekniklerle üretilen iki MPH'nin, tiroidektomi sonrası hemoraj ve drenajı azaltmada etkinliğini değerlendirmektir.

Gereç ve Yöntem: İstatistiksel güç analizi, her bir grup için \%95 gizli aralık içinde toplam 20 hastaya ihtiyaç duyulduğunu tahmin etmiştir. Hastalar her grupta 20 hasta olacak şekilde, Haemocer ${ }^{\mathrm{TM}}$ ve Arista ${ }^{\mathrm{TM}}$ gruplarına randomize edildi. Araştırmacı, cerrahı ameliyathanede her hasta için bilgilendirdi. Bilateral total tiroidektomi yapıldıktan sonra, ilk grupta ek işlemler uygulanmadı, ikinci gruba $5 \mathrm{~g} \mathrm{Haemocer}{ }^{\mathrm{TM}}$ uygulandı, operasyon alanına üçüncü grupta $5 \mathrm{~g}$ Arista $^{\mathrm{TM}}$ uygulandı ve operasyon çift taraflı yerleştirilerek sonlandııldı. Postoperatif birinci günde drenaj miktarı, kalsiyum, fosfor ve parathormon düzeyleri kaydedildi.

Bulgular: Yaş, cinsiyet, çıkarılmış doku ağırlı̆ı ve malign patoloji oranları açııından gruplar arasında anlamlı bir fark saptanmadı. Ayrıca ameliyat sonrası drenajlar ile kalsiyum (Ca), fosfor (P), parathormon (PTH) düzeylerinin gruplar arasında da anlamlı bir fark olmadığı belirlendi. Herhangi bir hastada ses kısıklığı ya da hematom görülmedi.

Sonuç: MPH'lerin postoperatif hemorajinin azaltılmasında etkinliği kanıtlanmamıştır ve bu gereksiz harcamalardan kaçınmanın anahtarı olabilir.

Anahtar Kelimeler: Mikropor, polisakkarit, hemosfer, tiroid, hemostaz

Doi: $10.5578 /$ turkjsurg.4162 